\title{
OPEN Author Correction: Evaluation of in vitro and in vivo antibiotic efficacy against a novel bioluminescent Shigella flexneri
}

Molly C. McCloskey, Shareef Shaheen, Lesley Rabago, Matthew A. Hulverson, Ryan Choi, Lynn K. Barrett \& Samuel L. M. Arnold

Correction to: Scientific Reports https://doi.org/10.1038/s41598-019-49729-2, published online 19 September 2019

The Acknowledgements section in this Article is incomplete.

"The authors recognize Wesley C. Van Voorhis MD, PhD of the University of Washington for his thoughtful discussions on the development of the models."

should read:

"The authors recognize Wesley C. Van Voorhis MD, PhD of the University of Washington for his thoughtful discussions on the development of the models. This work was funded by Tres Cantos Open Lab Foundation (Grant: TC246)."

(ic) Open Access This article is licensed under a Creative Commons Attribution 4.0 International License, which permits use, sharing, adaptation, distribution and reproduction in any medium or format, as long as you give appropriate credit to the original author(s) and the source, provide a link to the Creative Commons license, and indicate if changes were made. The images or other third party material in this article are included in the article's Creative Commons license, unless indicated otherwise in a credit line to the material. If material is not included in the article's Creative Commons license and your intended use is not permitted by statutory regulation or exceeds the permitted use, you will need to obtain permission directly from the copyright holder. To view a copy of this license, visit http://creativecommons.org/licenses/by/4.0/.

(C) The Author(s) 2020 